\title{
The influence of picocyanobacterial photosynthesis on calcite precipitation
}

\author{
${ }^{1}$ I. B. M. Kosamu; ${ }^{2}$ M. Obst \\ ${ }^{1}$ University of Malawi, The Polytechnic, Department of Physics and Biochemical Sciences, Private Bag 303, \\ Blantyre 3, Malawi \\ ${ }^{2}$ Swiss Federal Institute for Environmental Science and Technology, EAWAG, Limnological Research Centre, CH-6047 \\ Kastanienbaum, Switzerland \\ Received 9 November 2008; $\quad$ revised 26 April 2009; accepted 6 August 2009; $\quad$ available online 1 September 2009
}

\begin{abstract}
This study assessed the role of picocyanobacterial photosynthesis in the induction of calcite precipitation. It aimed at establishing whether photosynthetic uptake of bicarbonate by Synechoccoccus cells leads to calcite nucleation. The precipitation of calcite was initiated by addition of previously washed cyanobacterial cells of Synechococcus strain PCC 7942 to solutions of calcium carbonate at different saturation levels with respect to calcite. Precipitation experiments were performed under controlled laboratory conditions in two set-ups: one in which photosynthesis was inhibited using a herbicide called Diuron and the other one in which photosynthesis was taking place. During the experiments, a $\mathrm{pH}$ meter monitored the $\mathrm{pH}$ and ion selective electrodes monitored concentrations of carbonate and calcium ions. The morphology of the precipitated crystals was analysed using Scanning Electron Microscopy. When the kinetics of calcium carbonate nucleation by the Synechococcus cells were compared for the two sets of experiments, there were very little differences. In fact, the induction times for precipitation reactions with photosynthesis were shorter due to the uptake of carbon dioxide. It is therefore, concluded that photosynthesis does not directly influence the nucleation of calcite at the surface of Synechococcus cells with sufficient supply of carbon dioxide, i.e. cells took up carbon dioxide and not bicarbonate. The microscopic observations, however, provided some evidence that picocyanobacterial cell walls act as a template for calcite nucleation.
\end{abstract}

Keywords: Bacteria; Biomineralization; Crystal morphology; Ion selective electrodes; Scanning electron microscopy

\section{INTRODUCTION}

Recent studies have shown that there is a relationship between picocyanobacteria and calcite precipitation in both freshwater and marine systems (Thompson et al., 1997). Peaks of calcite concentration have been explained by the activity of autotrophic picoplankton (APP) in oligotrophic hard water bodies (Dittrich et al., 2004). After studying several lakes and parts of some oceans, Weisse (1993) observed that APP dominate the total phytoplankton production and biomass. Due to their small size, APP have the highest surface area to volume ratio of any group of living organisms and this, together with the presence of charged chemical groups on their cell surface, is responsible for their potent mineraladsorption and heterogeneous nucleation ability (Douglas and Beveridge, 1998). Riding (2000) reported that both heterotrophic and autotrophic bacteria are known to precipitate calcite in freshwater environments. Generally, previous research indicates that calcification by microalgae depends primarily on $\mathrm{CO}_{2}$ uptake while

ه *Corresponding Author Email: ikosamu@poly.ac.mw Tel: +265 1870 411; Fax: +265 1870578 cyanobacterial calcification may also rely on bicarbonate uptake. Several propositions have been put forward for freshwater bacteria and algae: McConnaughey (1989) suggested that the primary source of inorganic carbon involved in calcification is $\mathrm{CO}_{2}$; Thompson and Ferris (1990) presented a mechanism for $\mathrm{CaCO}_{3}$ precipitation by the picocyanobacteria Synechococcus. They argued that these freshwater bacteria use $\mathrm{HCO}_{3}^{-}$as a primary source of inorganic carbon. Merz-Preiss (2000) presented a model similar to Thompson and Ferris (1990) for calcification by freshwater cyanobacterium Scytonema. Results of biomineralization experiments with unicellular green algae Nannochalis atomus (Yates, 1996) were consistent with the model presented by McConnaughey (1989). The results of these experiments indicated that intracellular $\mathrm{Ca}^{2+}$ was incorporated into intracellular $\mathrm{CaCO}_{3}$. Despite several modeling and experimental studies on mechanisms for calcite biomineralization, it is still not possible to clearly state the contributions of the proposed mechanisms especially in picocyanobacteria (McCannaughey, 1989; Thompson 
and Ferris, 1990; Merz and Zankl, 1993; Yates, 1996). There are three mechanisms which are supposed to be responsible for calcium carbonate mineralization by picoplankton:

- biologically induced precipitation due to a change of the chemical environment near the cell wall because of photosynthesis;

- biologically controlled biomineralization where the cell surface acts as a nucleation site, and;

- biologically governed process where active ion exchange processes of the cells lead to $\mathrm{CaCO}_{3}$ formation.

This study assesses the role of picocyanobacterial photosynthesis in inducing calcite precipitation. The study focuses on the biologically induced precipitation due to a change of the chemical environment near the cell wall because of photosynthesis. The effect of photosynthesis inhibition on biotic calcite nucleation and growth was investigated by blocking photosystem II of Synechoccoccus strain PCC 7942 using a herbicide called Diuron. Induction times for experiments with and without Diuron were compared. The study was carried out at the Swiss Federal Institute of Environmental Science and Technology (EAWAG) in Switzerland from October 2003 to March 2004.

\section{MATERIAL AND METHODS}

Precipitation experiments

Precipitation experiments were carried out using four simultaneously running reaction vessels $(750 \mathrm{~mL}$ fivenecked flasks). These vessels were placed in a thermostatically (Colora K3 DS) operated water bath in front of a full spectrum fluorescent tube (Phillips TLD 58W/950CE) emitting a total radiance of $13 \mu / \mathrm{Em}^{2} \mathrm{~s}^{1}$ at a colour temperature of $5400 \mathrm{~K}$ (Colour temperature means the temperature of an ideal black body radiator at which the colour of a light source and the black body are identical. Colour temperatures are normally expressed in kelvins (K). (Note that the term degrees kelvin is not technically correct). The water bath was maintained at $20^{\circ} \mathrm{C}$ which is a typical water temperature in most water bodies. Solutions were continuously stirred with Heidolph MR 2002 magnetic stirrers. During the whole series of experiments, four electrodes were used to monitor $\mathrm{pH}$, ion activities of $\mathrm{Ca}^{2+}$ and $\mathrm{CO}_{3}{ }^{2-}$, temperature and electrical conductivity in the precipitation reactors. These electrodes were the combination of $\mathrm{pH}$ electrodes (Mettler Toledo In Pro 3030) for pH, polyvinyl chloride (PVC)-based liquid membrane ion selective electrodes for $\mathrm{Ca}^{2+}$ and $\mathrm{CO}_{3}^{2-}$ activities and the Wissenschaftlich
Technische Werkstatten (WTW) Tetracon 325 electrodes for electrical conductivity and temperature. All the data were collected as average values for three min intervals. The liquid membranes for $\mathrm{Ca}^{2+}$ and $\mathrm{CO}_{3}{ }^{2-}$ ion selective electrodes were prepared by using neutral carriers for $\mathrm{Ca}^{2+}$ (Ionophore II, ETH 129) and $\mathrm{CO}_{3}{ }^{2-}$ (Ionophore II, ETH 6019) available from Fluka Inc., Switzerland. The PVC-based membranes were cast and mounted into commercially available electrode bodies (Fluka Inc.). These membranes consist mainly of ion selective ligands. The solutions were prepared to represent two different setups: one in which photosynthesis was inhibited using Diuron (a herbicide) and the other one in which photosynthesis was operational. All chemicals were p.a. grade from Fluka Inc., Switzerland, unless otherwise stated. Bicarbonate solutions were prepared by the addition of $630.08 \mathrm{mg}$ of sodium bicarbonate, puris p.a. (Fluka 71628) to five L of nanopure water to give a $1.5 \mathrm{mM}$ bicarbonate solution. $700 \mathrm{~mL}$ of this solution was poured into each of the four $750 \mathrm{~mL}$ reaction vessels. In order to equilibrate the sodium bicarbonate solution with atmospheric conditions, the solution was bubbled with $\mathrm{CO}_{2}$ (504 ppm) through syringe needles before $\mathrm{CaCl}_{2}$ solution was added. Stock solutions of $\mathrm{CaCl}_{2}$ were prepared by adding calcium chloride dihydrate puris p.a. (Fluka 21101) to nanopure water. The amount of $\mathrm{CaCl}_{2}$ that was added to the $750 \mathrm{~mL}$ reactors was calculated based on the required saturation states with respect to calcite. The saturation indices were between 4.5 and 7.5. A similar approach, using one reactor, has successfully been used by Dittrich et al., 2004. A computer program called PHREEQC Interactive (Version 2.7.1 (2)) was used to calculate the supersaturations and the equilibrium concentrations of the species in solution were obtained by using the Lawrence Livermore National Library (LLNL) database. Synechococcus cell suspensions, a unicellular freshwater strain of approximately $0.5 \mu \mathrm{m}$ (PCC 7942 Pasteur Institute, Paris, France), were grown in a $2.5 \mathrm{~L}$ chemostat using $\mathrm{Z} / 10$ culture medium. The cells were then recovered by centrifuging the cell suspensions three times at 2000rpm for 20 min using Eppendorf centrifuge (5804 R having a Y025 rotor) at $20^{\circ} \mathrm{C}$. The supernatant was removed leaving approximately $5 \mathrm{~mL}$ of concentrated cells in suspension. The cells were also washed three times in nanopure water. Then, the living cells (as shown by microscopic investigation) were added to the reactors to start the precipitation experiments. The number of cells in each reaction vessel was established as follows: An aliquot of approximately $5 \mathrm{~mL}$ of the solution was passed through 
a $0.2 \mu \mathrm{m}$ polycarbonate black nucleophore filter. Synechococcus cells were counted by examining the filters under an epifluorescence microscope (Zeiss Axiolab), mounted with a Neofluar 100X objective, Optivar 1.6X and E-PI 10X Ocular with a total magnification of $1600 X$. On each filter, 300 to 400 cells were counted.

\section{Analysis of the calcite precipitates}

At the end of the experiments, $2 \mathrm{~mL}$ aliquots of the solution from each of the four reaction vessels were filtered through $0.2 \mu \mathrm{m}$ nucleophore polycarbonate filters in millipore-swinnex filter cartridges. These filters were washed with $2 \mathrm{~mL}$ nanopure water to remove all soluble salts. Then the filters containing the residue were vacuum-filtered until completely dry and were stored in petri dishes at $4{ }^{\circ} \mathrm{C}$. The dry filters were mounted onto aluminium stubs in order to analyse the morphology of the calcite crystals. These stubs were sputter-coated with a thin layer of platinum prior to viewing. The morphology of the calcite precipitates was characterised by scanning electron microscopy (SEM, Phillips XL30, $\mathrm{LaB}_{6}$ filament).

\section{RESULTS AND DISCUSSION}

Analysis of the precipitation experiments

Six experiments were run to determine the calcium concentrations at which precipitation would occur without blocking photosynthesis. After establishing the required calcium concentrations, two sets of experiments were run to investigate the effect of blocking photosynthesis on calcite precipitation. In both cases, equilibration with an artificial atmosphere resulted in an increase in $\mathrm{pH}$ values from around 7.8 to 8.2 within $10 \mathrm{~h}$. This was the maximum $\mathrm{pH}$ which remained constant until precipitation took place. The constant $\mathrm{pH}$ of 8.2 indicated a successful attainment of a metastable $\mathrm{Ca}^{2+} / \mathrm{CO}_{3}{ }^{2-}$ equilibrium. Thus the open system approach resulted in the stable $\mathrm{pH}$ until precipitation took place. Consequently, a drop in $\mathrm{pH}$ and the lowering of calcium concentration (calculated from conductivity values) were indications of calcite precipitation. Thus a decrease in calcium concentration is related to a corresponding decrease in alkalinity. At saturation values of around 6 and above, the $\mathrm{pH}$ dropped to around 7.9 within $40 \mathrm{~h}$ of reaction time. There was, however, no drop in $\mathrm{pH}$ values for saturations of around 5 even after $100 \mathrm{~h}$ of reaction time. The absence of calcite precipitation at $\mathrm{pH}$ values below 7.9 might have been due to a shift in response to cellular metabolism as a result of the changing hydrogen ion concentration. Normally, cells maintain intracellular $\mathrm{pH}$ levels and they shift the ratio of $\left[\mathrm{H}^{+}\right]_{\text {in }} /\left[\mathrm{H}^{+}\right]_{\text {out }}$ in response to changes in $\mathrm{pH}$. While there are some ion fluxes that play a role in generating microenvironments for calcification (Yates, 1996), the effects of cellular stress due to changing environmental conditions remain to be examined. However, the absence of precipitation below pH 7.9 should emphasize the role of cellular metabolism in the process of calcite precipitation. The use of $\mathrm{Ca}^{2+}$, $\mathrm{CO}_{3}{ }^{2-}$ and $\mathrm{pH}$ electrodes during the experiments proved to be an effective way to monitor calcite precipitation reactions. Precipitation experiments followed three steps of induction, precipitation process and aftermath. This was similar to the observations made by Hartley et al. (1995). The lengths of the various stages were also comparable to studies by Obst et al. (2002) and Dittrich et al. (2004). Initial saturations were not higher than those found in natural environments (Stabel, 1986); therefore, the results from this study may be applicable to natural water bodies. The addition of equal amounts of cells to the precipitation reactors ensured comparable photosynthetic rates in the reactors and therefore the length of induction times only depended on the saturation of the solutions. Schultze-Lam et al. (1992), indicated that precipitation of calcite and the subsequent shedding off of the calcified cell wall are actually important for the Synechococcus cells as they help them to escape the suicidal effect of their own metabolism. Several authors have argued that the induction of calcite precipitation is caused by the metabolic uptake of $\mathrm{HCO}_{3}^{-}$ (Ferrer et al., 1988; Erlich, 1998; Thompson and Ferris, 1990; Hammes and Verstraete, 2002; Rivadenerya et al., 1994; Dittrich and Obst, 2004). The authors have suggested that during photosynthesis, $\mathrm{HCO}_{3}^{-}$is transported through the membrane and dissociates within the cell into $\mathrm{CO}_{2}$ and $\mathrm{OH}^{-}$(this equilibrium may be shifted further towards $\mathrm{CO}_{2}$ and $\mathrm{OH}^{-}$by the enzymatic action of Carbonic anhydrase). $\mathrm{CO}_{2}$ is removed from the equilibrium by photosynthesis, leaving excess $\mathrm{OH}^{-}$. The excess $\mathrm{OH}$ - is pumped out of the cell through the cell membrane where it causes a rise in $\mathrm{pH}$ in the outer membrane of the cell. The rise in $\mathrm{pH}$ causes the carbonic acid equilibrium to shift towards an increase in $\left[\mathrm{CO}_{3}{ }^{2-}\right]$ resulting into a very sharp, local increase in $\mathrm{CaCO}_{3}$ oversaturation. If very high saturation indices are reached, nucleation will take place close to the cell after which crystal growth continues (Lowenstam and Wiener, 1989). Thompson et al. (1997), showed that only light exposed and consequently photosynthesizing cells are able to induce calcite precipitation. Yates and Robbins 


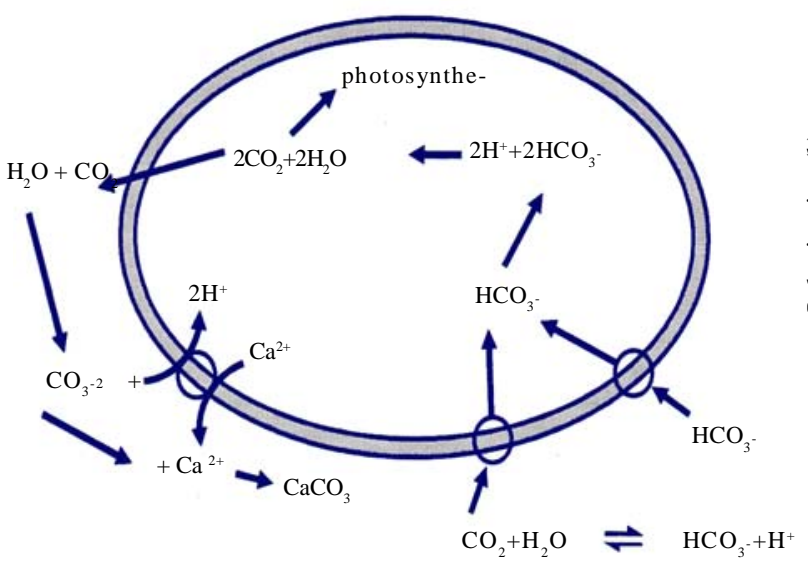

Fig. 1: Theoretical model for calcite precipitation induced by picocyanobacteria from Yates, 1999

(1999) presented the induction of calcite precipitation by picocyanobacteria using the model in Fig. 1. Electron transport in photosynthesis can be inhibited in the presence of certain compounds that act as herbicides. These compounds are usually structural analogues of the mobile electron carrier in photosynthesis called $Q_{B}$, a nonpolar plastoquinone. These analogues, such as Diuron (3-(3,4-dichlorophenyl)-1,1dimethyl urea), inhibit electron transport by blocking the binding site of $\mathrm{Q}_{B}$ on photosystem II. Diuron inhibits both the photosynthetic oxygen evolution and the reduction of the terminal electron acceptor, NADP+, which finally turns off the reductive pentose phosphate cycle (Werner et al., 2002). It was, therefore, expected during the study that Diuron would inhibit photosystem II in Synechococcus cells but it would allow photosystem I to operate. The blocking of photosystem II helped to determine whether the uptake of $\mathrm{HCO}_{3}{ }^{-}$by the cells during photosynthesis leads to calcite nucleation. Comparison of experiments in which photosynthesis was blocked with those in which photosynthesis was operational showed that calcite nucleation occurred earlier (shorter induction times) in experiments in which photosynthesis was blocked (Fig. $3)$. The blocking of photosystem II by $1 \mu \mathrm{m}$ Diuron favoured calcite precipitation. While calcite maybe linked to Synechococcus cells, these results indicate that alteration of the microenvironment around the cells due to the photosynthetic uptake of $\mathrm{HCO}_{3}{ }^{-}$does not play an important role in the process. It is concluded, therefore, that photosynthesis does not directly influence the nucleation of calcite at the surface of Synechococcus cells with sufficient supply of $\mathrm{CO}_{2}$, i.e. cells took up $\mathrm{CO}_{2}$ and not $\mathrm{HCO}_{3}^{-}$. It may be inferred that the main

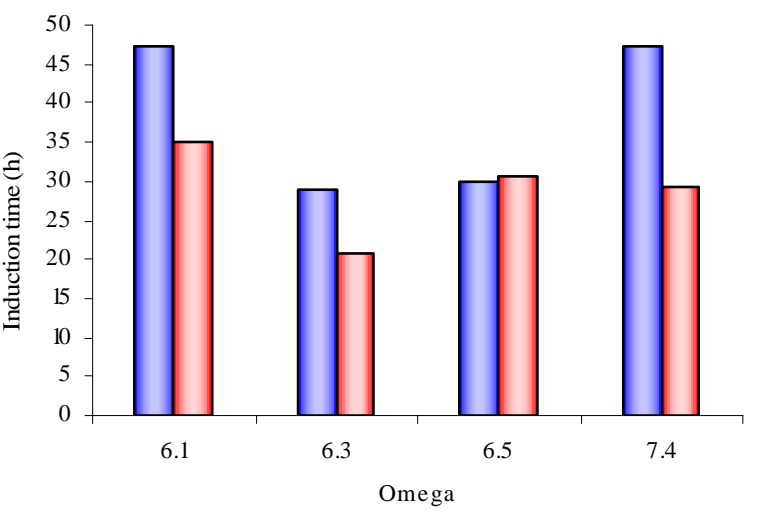

$\square$ Cells only $\square$ Cells plus Diuron

Fig. 2: The blocking of electron transport in the photosystem II by Diuron resulted in earlier precipitation

mechanism for picocyanobacterial calcite precipitation may either be a biologically controlled process in which the cell surface acts as a nucleation site or it might be through an enzymatically driven process that is not negatively affected by Diuron. These results differ from earlier propositions (Stipp, 1999; Thompson et al., 1997) that bicarbonate uptake by photosynthesis releases $\mathrm{OH}^{-}$ ions which are responsible for local $\mathrm{pH}$ rise in the microenvironment leading to calcite precipitation by APP. As APP stands for a very large group of organisms, the earlier postulations may be true for some species but not for Synechoccoccus strain PCC 7942. Literature shows that few studies have been done on the cell membranes or the microenvironment of Synechococcus cells (Erez, 1983; Farquhar et al., 1989; Arakaki and Mucci, 1995; Lotter et al., 1997; Douglas and Beveridge, 1998; House, 1999) hence biological induction of calcite precipitation may still be debatable. It may be possible that the cell wall of the Synechococcus may produce extracellular polymeric substances (EPS), which may be responsible for changing the environments of the cells leading to induction of calcite precipitation (compare Kawaguchi and Decho, 2002). For both sets of experiments (with and without Diuron) and within the saturation values of 6.1, 6.3, 6.5 and 7.4, the induction time for calcite precipitation was shortest at a saturation of 6.3. This appears to be the best saturation value for calcite precipitation by Synechococcus at an alkalinity of $1.5 \mathrm{mM}$ and at $504 \mathrm{ppm} \mathrm{CO}_{2}$. Due to the few experiments conducted the present correlation can only serve as a trend and more studies need to be done to verify the current observations. 


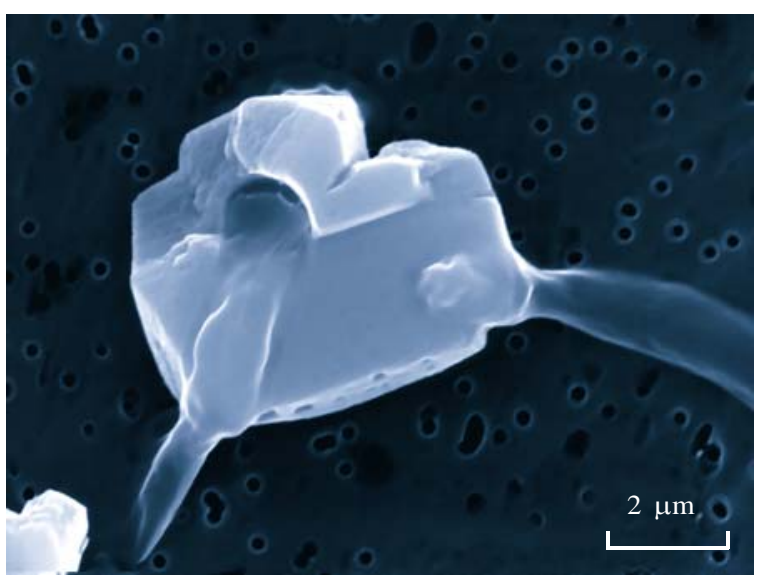

Fig. 3: Attachment of calcite crystal to Synechococcus cells

\section{Crystal morphology}

Due to some technical problems, it was only possible to analyse filters from the precipitation experiments in which Diuron was not added. Consequently no comparisons are made of the morphology of the crystals from the two sets of experiments. SEM analysis of filters from the precipitation experiments revealed calcite crystals with length ranging from $500 \mathrm{~nm}$ up to $5 \mu \mathrm{m}$. They had well-developed rhombohedral morphology and in most cases they also had sharp but cracked edges. Some filters showed some fine grains of calcite on the cell walls of Synechococcus cells indicating an early stage of nucleation with the cell wall acting as a template for nucleation as shown in Fig. 3 (compare Schultze-Lam et al., 1992). The faces of the larger crystals showed hollow, rod-like impressions and on the basis of shape and size, it was inferred that these were the spaces housed by the Synechococcus cells when they interfered with crystal growth (Fig. 4). The hollow impressions on calcite underline the involvement of cells in crystal formation. The crystals had smooth rhombohedral side face very similar to those obtained by Obst et al. (2002). The biological origin of calcite was clearly highlighted by the SEM observations as the crystals were seen forming around a network of Synechococcus cells. The SEM observations, therefore, confirm that Synechococcus cells are involved in calcite precipitation and as such the SEM is a vital tool for establishing the behaviour of picocyanobacterial calcite precipitation.

\section{CONCLUSION}

It is concluded that photosynthesis does not directly influence the nucleation of calcite at the surface of

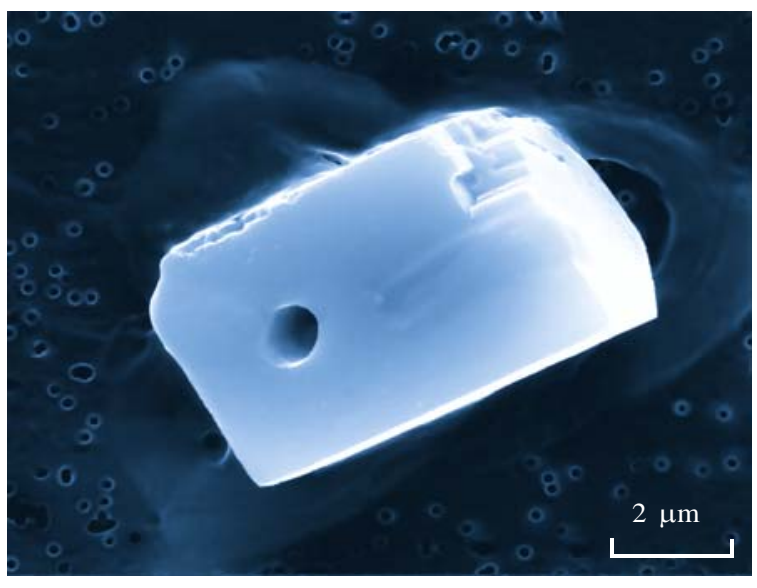

Fig. 4: Details of a hollow impression on calcite

Synechococcus cells with sufficient supply of $\mathrm{CO}_{2}$, i.e. cells took up $\mathrm{CO}_{2}$ and not $\mathrm{HCO}_{3}^{-}$. The results show that cells of Synechococcus strain PCC 7942 are involved in calcite precipitation but alteration of the microenvironment of cells due to photosynthesis did not show any enhancement of calcite precipitation. Thus a direct chemical linkage between photoassimilation of $\mathrm{HCO}_{3}$ and picocyanobacterial calcite precipitation seems unlikely. The induction times for experiments in which blocked photosynthesis were actually shorter than those in which photosynthesis was operational. This is because the precipitation reaction was slightly accelerated by photosynthetic uptake of $\mathrm{CO}_{2}$. Pictures from Scanning Electron Microscopy indicate that there is involvement of the cell walls of Synechococcus strain PCC 7942 in calcite nucleation. Further research needs to focus more on biologically controlled biomineralization where the cell surface acts as a nucleation site and on biologically governed process where active ion exchange processes of the cells lead to $\mathrm{CaCO}_{3}$ formation.

\section{ACKNOWLEDGEMENTS}

The authors are grateful to the Swiss Government through EAWAG (Swiss Federal Institute of Aquatic Science and Technology) for funding this study. The authors are greatly indebted to Dr. Maria Dittrich and Dr. Kelderman for their comments on this paper. Thanks should also go to Mr. L. Ndalama, Mr. P. Mhagama, Mrs. D. Lakudzala and Ms. M. Kamwaza for the time they spent checking the document. 


\section{REFERENCES}

Arakaki, T.; Mucci, A., (1995). A continuous and mechanistic representation of calcite reaction-controlled kinetics in dilute solutions at $25^{\circ} \mathrm{C}$ and $1 \mathrm{~atm}$ total pressure. Aquat. Geochem., 1 (1), 105-130 (26 pages).

Dittrich, M.; Kurz, P.; Wehrli, B., (2004). The role of autotrophic picocyanobacteria in calcite precipitation in an oligotrophic lake. Geomicrobiol. J., 21 (1), 45-53 (9 pages).

Dittrich, M.; Obst, M., (2004). Are picoplankton responsible for calcite precipitation in lakes? Ambio, 33 (8), 559-564 (6 pages).

Douglas, S.; Beveridge, T. J., (1998). Mineral formation in natural microbial communities. FEMS Microbiol. Ecol., 26 (2) 7988 (10 pages).

Erez, J., (1983). Calcification rates, photosynthesis and light in planktonic foraminifera. In Biomineralization and Biological Metal Accumulation Westbroek, P.; DeJong, E. W. (Eds.), D. Reidel Publishing Company, 307-312.

Erlich, H. L., (1998) Geomicrobiology: Its significance for geology. Earth Sci. Rev., 45 (1-2), $45-60$ (16 pages).

Farquhar, G. D.; Ehleringer, J. R.; Hubick, K. T., (1989). Carbon isotope discrimination and photosynthesis. Annu. Rev. Plant Phys., 40, 503-537 (35 pages).

Ferrer, R. M.; Quevedo-Sarmiento, J.; Rivadeneyra, M. A.; Bejar, V.; Delgado, R.; Ramos-Cormenzana, A., (1988). Calcium carbonate precipitation by two groups of moderately halophilic microorgenisms at different temperatures and salt concentrations. Curr. Microbiol., 17 (4), 221-227 (7 pages).

Hammes, F.; Verstraete, W., (2002). Key roles of pH and calcium metabolism in microbial carbonate precipitation. Rev. Environ. Sci. Biotech., 1 (1), 3-7 (5 pages).

Hartley, A. M.; House, W. A.; Callow, M. E.; Leadbeater, B. S. C., (1995). The role of a green alga in the precipitation of calcite and the coprecipitation of phosphate in freshwater. Int. Rev. Geasmten Hydrobiol., 80 (3), 385-401 (17 pages).

House, W., (1999). The physico-chemical conditions for the precipitation of phosphate with calcium. Environ. Tech., 20 (7), 727-733 (7 pages).

Kawaguchi, T.; Decho, A. W., (2002). Isolation and biochemical characterization of extracellular polymeric secretions (EPS) from modern soft marine stromatolites (Bahamas) and its inhibitory effect on $\mathrm{CaCO}_{3}$ precipitation. Prep. Biochem. Biotech., 32 (1), 51-63 (13 pages).

Lotter, A. F.; Sturm, M.; Wehrli, B., (1997). Varve formation since 1885 and high-resolution varve analyses in hypertrophic Baldeggersee (Switzerland). Aqua. Sci., 59 (4), 304-325 (22 pages).

Lowenstam, H. A.; Weiner, S. (1989). On biomineralization. Oxford University Press, New York, 336.
McConnaughey, T. A., (1989). Biomineralization mechanisms. In origin, evolution and Modern aspects of biomineralization in plants and animals Crick, R. E. (Ed.), Plenum Press, 57-73.

Merz, M. U. E.; Zankl, H., (1993). The influence of culture conditions on growth and sheath development of calcifying cyanobacteria. Facies., 29 (1), 75-80 (6 pages).

Merz-Preiss, M., (2000). Calcification in cyanobacteria. In microbial sediments Riding, R. E.; Awramik, S. M. (Eds.), Springer Verlag, Berlin, Heidelberg, New York. 50-56.

Obst, M.; Dittrich, M.; Marvrocordatos, D.; Wehrli, B., (2002). Calcite formation by picoplankton. The $12^{\text {th }}$ Annual V. M. Goldschimdt Conference, A566. Davos, Switzerland.

Riding, R., (2000). Microbial carbonates: The geological record of the calcified bacterial-algal mats and biofilms. Sedimentology., 47 (1), 179-214 (36 pages).

Rivadeneyra, M. A.; Delgado, R.; Del Moral, A.; Ferrer, R. M.; Ramos-Cormenzana, A., (1994). Precipatation of calcium carbonate by Vibrio spp. from an inland saltern. FEMS Microbiol. Ecol., 13 (3), 197-204 (8 pages).

Schultze-Lam, S.; Harauz, G.; Beveridge, T. J., (1992). Participation of a cyanobacterial S-layer in fine-grain mineral formation. J. Bacteriol., 174 (24), $7971-7981$ (11 pages).

Stabel, H. H., (1986). Calcite precipitation in lake constance: Chemical equilibrium, sedimentation, and nucleation by algae. Limnol. Oceanogr., 31 (5), 1081-1093 (13 pages).

Stipp, S. L. S., (1999). Toward a conceptual model of the calcite surface: Hydration, hydrolysis, and surface potential. Geochim. Cosmochim. Ac., 63 (19-20), 3121-3131 (11 pages).

Thompson, J. B.; Schultze-Lam, S.; Beveridge, T. J.; Des-Marais, D. J., (1997). Whiting events: Biogenic origin due to the photosynthetic activity of cyanobacterial picoplankton. Limnol. Oceanogr., 42 (1), 133-141 (9 pages).

Thompson, J. B.; Ferris, F. G., (1990). Cyanobacterial precipitation of gypsum, calcite and magnesite from natural alkaline lake water. Geology., 18 (10), 995-998 (4 pages).

Weisse, T., (1993). Dynamics of autotrophic picoplankton in marine and freshwater ecosystems. In Jones, J. G. (Ed). Adv. Microb. Ecol., 13, 328-370 (43 pages).

Werner, D.; Behrsign, O.; Scharte, G.; Woller., J.; Steup, M.; Micheel, B., (2002). Monoclonal nati-diuron antibodies prevent inhibition of photosynthesis by Diuron. FEBS Lett., 523 (1-3), 95-98 (4 pages).

Yates, K. K., (1996). Microbial precipitation of calcium carbonate: A potential mechanism for lime-mud production. University of South Florida. Ph.D. Dissertation. Tampa, Florida.

Yates, K. K.; Robbins, L. L., (1999). Radioisotope tracer studies of inorganic carbon and $\mathrm{Ca}$ in microbilogically derived $\mathrm{CaCO}_{3}$. Geochim. Cosmochim. Ac., 63 (1), 129-136 (8 pages).

\section{AUTHOR (S) BIOSKETCHES}

Kosamu, I. B. M., M.Sc., University of Malawi, The Polytechnic, Department of Physics and Biochemical Sciences, Private Bag 303, Blantyre 3, Malawi. Email: ikosamu@poly.ac.mw

Obst, M., Ph.D., Swiss Federal Institute for Environmental Science and Technology, EAWAG, Limnological Research Centre, CH-6047 Kastanienbaum, Switzerland. Email: martin.obst@eawag.ch

How to cite this article: (Harvard style)

Kosamu, I. B. M.; Obst, M., (2009). The inluence of picocyanobacterial photosynthesis on calcite precipitation. Int. J. Environ. Sci. Tech., $6(4), 557-562$. 